HorTSCIENCE 26(5):553-555. 1991.

\title{
Ethephon and 2,4-D Do Not Improve Periderm Color and May Decrease Yield in Red-skinned 'Norland' Potato
}

\author{
Vincent A. Fritz ${ }^{1}$ and James B. Hebel ${ }^{2}$ \\ Southern Experiment Station, University of Minnesota, Waseca, \\ MN 56093
}

\author{
Alicia M. Borowski and Patricia E. Hung ${ }^{3}$ \\ Department of Horticultural Science, University of Minnesota, St. Paul, \\ MN 55108 \\ Additional index words. ethylene, Solarium tuberosum
}

\begin{abstract}
Ethephon and 2,4-D were foliarly applied to red-skinned 'Norland' potatoes (Solarium tuberosum L.) to determine if periderm color could be enhanced at harvest and throughout storage. Base rates of 250 and $185 \mathrm{ml} \cdot \mathrm{liter}^{-1}$ for ethephon and 2,4-D, respectively, were applied at the onset of tuberization (tubers $\geq 2.5 \mathrm{~cm}$ in diameter). Base or double-rate foliar applications of either ethephon or 2,4-D resulted in significant U.S. No. 1 yield reductions and did not affect periderm color intensity at harvest or throughout storage sufficiently to warrant their use. Chemical names used: (2chloroethyl)phosphonic acid (ethephon), (2,4 -dichlorophenoxy) acetic acid (2,4-D).
\end{abstract}

A deep-red periderm pigmentation that is retained in storage is a desirable fresh-market quality characteristic in red potatoes. Foliar applications of 2,4-D have been used commercially to stimulate ethylene production and promote the production of anthocyanin, the red pigment responsible for the periderm color (Nelson and Bristol, 1975). However, the use of 2,4-D has often given inconsistent periderm color results and reduced yields.

Ethephon and other ethylene-generating compounds have been used to enhance anthocyanin production and color in solanaceous fruits, including pepper (Capsicum annuum L.) (Armitage, 1989; Cantliffe and Goodwin, 1975; Knavel and Kemp, 1973; Worku et al., 1975) and tomato (Lycopersicon esculentum Mill.) (Burg and Burg, 1965; Edwards et al., 1984).

The primary objectives of our study were to determine if foliar-applied ethephon or 2,4-D, either as a single or split application,

Received for publication 27 Apr. 1990. Minnesota Agr. Expt. Sta. Journal Series no. 18,122. The cost of publishing this paper was defrayed in part by the payment of page charges. Under postal regulations, this paper therefore must be hereby marked advertisement solely to indicate this fact.

${ }^{1}$ Assistant Professor.

${ }^{2}$ Senior Research Plot Coordinator.

${ }^{3}$ Graduate Assistant. would enhance red pigmentation in the periderm of red-skinned 'Norland' potatoes and to note any effect on yield or quality.

Preliminary studies in 1986 included ethephon concentrations as high as 1500 and 2500 ml-liter ${ }^{-1}$ and 2,4-D concentrations of 185 and $370 \mathrm{ml} \cdot \mathrm{liter}^{-1}$. The results were used as a basis for selecting ethephon and 2,4-D concentrations in 1987 and 1988 that would not severely reduce tuber yield or quality (data not shown). Ethephon and 2,4-D (ester) concentrations used are listed in Table 1. Both chemicals were foliarly applied with a nonionic surfactant (X-77) (Valent USA Corp., Dallas Center, Iowa) at $0.05 \%$ (v/v) using a $\mathrm{CO}$, bicycle sprayer equipped with 8002 flat fan nozzles and calibrated to deliver 380 liters $\cdot$ ha $^{-1}$

We used a randomized complete block design with four replications. Each plot consisted of four rows, each $12 \mathrm{~m}$ long. Plant spacing was $20 \mathrm{~cm}$ and $90 \mathrm{~cm}$ within and between rows, respectively. Seed pieces of 'Norland' were planted during the 3rd week of May on a calcareous Palms muck (loamy, mixed, euic, mesic Terric Medisaprists). The soil had a $\mathrm{pH}$ (1 soil : 1 water) of 7.3; extractable $\mathrm{P}\left(\right.$ Bray $\mathrm{P}_{1}$ ) and $\mathrm{K}$ (ammonium acetate) were 138 and $372 \mathrm{mg} \cdot \mathrm{liter}^{-1}$, respectively. Before planting, $91 \mathrm{~kg} \mathrm{~N} / \mathrm{ha}$ was broadcast and incorporated. The pesticides (3-phenoxyphenol)methyl $( \pm)$-cis, trans-3(2,2-dichloro-ethenyl) -2,2-dimethylcyclo- 
Table 1. Effect of foliar-applied ethephon and 2,4-D on yield of red-skinned 'Norland' potatoes.

\begin{tabular}{|c|c|c|c|c|}
\hline \multirow{3}{*}{$\begin{array}{l}\text { Treatment } \\
\left(\text { ml }^{\left.- \text {liter }^{-1}\right)}\right. \\
\end{array}$} & \multicolumn{4}{|c|}{ Yield $\left(\mathrm{Mg} \cdot \mathrm{ha}^{-1}\right)^{\mathrm{z}}$} \\
\hline & \multicolumn{2}{|c|}{ U.S. No. 1} & \multicolumn{2}{|c|}{ B } \\
\hline & 1987 & 1988 & 1987 & 1988 \\
\hline \multicolumn{5}{|l|}{ Ethephon } \\
\hline 250 & 28.2 & $28.1 \mathrm{ab}$ & $1.7 \mathrm{~b}$ & $3.2 \mathrm{bc}$ \\
\hline 500 & 26.6 & $28.1 \mathrm{ab}$ & $2.1 \mathrm{ab}$ & $3.0 \mathrm{c}$ \\
\hline $250+250$ & 25.4 & $23.9 \mathrm{~b}$ & $2.9 \mathrm{a}$ & $5.0 \mathrm{a}$ \\
\hline \multicolumn{5}{|l|}{ 2,4-D (ester) } \\
\hline 185 & 28.8 & $27.1 \mathrm{ab}$ & $2.0 \mathrm{ab}$ & $3.6 \mathrm{bc}$ \\
\hline $185+185$ & 26.1 & $23.4 \mathrm{~b}$ & $2.9 \mathrm{a}$ & $3.9 \mathrm{abc}$ \\
\hline \multicolumn{5}{|l|}{ Surfactant only } \\
\hline$(\mathrm{X}-77$ at $0.05 \%)$ & 27.0 & $28.0 \mathrm{ab}$ & $2.6 \mathrm{ab}$ & $3.5 \mathrm{bc}$ \\
\hline Nontreated control & 28.1 & $30.4 \mathrm{a}$ & $2.3 \mathrm{ab}$ & $2.7 \mathrm{c}$ \\
\hline Significance & NS & $* *$ & $* *$ & $* *$ \\
\hline
\end{tabular}

${ }^{2}$ Mean comparisons within columns by the Duncan-Wailer test.

Ns,**Not significant or significant at $P \leq 0.01$, respectively-

Table 2. Monthly air temperature averages for 1987 and 1988.

\begin{tabular}{llll}
\hline \hline & \multicolumn{3}{c}{ Avg. air temp $\left({ }^{\circ} \mathrm{C}\right)$} \\
\cline { 2 - 3 } Month & 1987 & 1988 & LTx $^{2}$ \\
\hline June & 21.5 & 23.3 & 19.5 \\
July & 23.3 & 23.7 & 21.8 \\
August & 19.5 & 22.7 & 20.4 \\
\hline
\end{tabular}

${ }^{2}$ Thirty-year average, 1951 through 1980 .

propanecarboxylate (permethrin) and zinc ion and manganese ethylene bisdithiocarbamate (mancozeb) were sprayed, as needed, for insect and disease control at rates of 0.2 and $1.8 \mathrm{~kg} \cdot \mathrm{ha}^{-1}$, respectively. Weeds were controlled through the use of 4-amino- 6 - $(1,1-$ dimethylethyl)-3-(methylthio)-1,2,4-triazin5(4H)-one (metribuzin) applied preemergence at a rate of $1.1 \mathrm{~kg} \cdot \mathrm{ha}^{-1}$ and hand weeding, as necessary. Plots were not irrigated.

Base rates of 250 and $185 \mathrm{ml} \cdot \mathrm{liter}^{-1}$ for ethephon and 2,4-D, respectively, were foliarly applied at the onset of tuberization, i.e., when plants had several tubers $\geq 2.5 \mathrm{~cm}$ in diameter. This stage was determined by hand-digging sample plants. Double-rate treatments were applied either in a single or split application, with 10 days between the initial and final applications.

At harvest, only tubers from $12 \mathrm{~m}$ of the inner two rows were collected to exclude treatment drift effects on yield and periderm coloration. Tubers were sized and graded into

Table 3. Periderm color intensity at harvest and throughout storage of red-skinned 'Norland' potato tubers foliarly treated with ethephon or 2,4-D in 1988.

\begin{tabular}{|c|c|c|c|}
\hline \multirow{2}{*}{$\begin{array}{l}\text { Treatment } \\
\left(\mathrm{ml} \cdot \text { liter }^{-1}\right)\end{array}$} & \multicolumn{3}{|c|}{ Date of sampling } \\
\hline & 27 Sept. & 20 Dec. & 23 Mar. \\
\hline & \multicolumn{3}{|c|}{$\%$ Absorbance $^{2 y}$} \\
\hline \multicolumn{4}{|l|}{ Ethephon } \\
\hline 250 & 22.7 & $22.4 \mathrm{abc}$ & 21.3 \\
\hline 500 & 23.0 & $22.2 \mathrm{bc}$ & 22.2 \\
\hline $250+250$ & 23.2 & $24.2 \mathrm{a}$ & 22.4 \\
\hline \multicolumn{4}{|l|}{ 2,4-D (ester) } \\
\hline 185 & 22.8 & $21.4 \mathrm{c}$ & 23.1 \\
\hline $185+185$ & 25.0 & $24.3 \mathrm{a}$ & 24.4 \\
\hline \multicolumn{4}{|l|}{ Surfactant only } \\
\hline$(\mathrm{X}-77$ at $0.05 \%)$ & 23.5 & $20.8 \mathrm{c}$ & 21.4 \\
\hline Nontreated control & 22.0 & $20.7 \mathrm{c}$ & 22.1 \\
\hline Significance & NS & & NS \\
\hline
\end{tabular}

${ }^{2}$ Spectrophotometer analysis conducted at a 535-nm wavelength.

Mean comparisons within columns by the Duncan-Wailer test.

,$* *$ Not significant or significant at $P \leq 0.01$, respectively. suggest that potatoes were more sensitive to double-rate applications of either chemical (Table 1). This trend is supported by an increase in grade B tubers from plants receiving a split application of the double rate of ethephon or a double rate of 2,4-D when compared to the base rate of ethephon. Treatments did not affect periderm color at harvest (data riot shown).

In 1988, the split, double-rate application of ethephon decreased U.S. No. 1 tuber yield and increased grade B tuber yield compared to the nontreated control. The double-rate application of 2,4-D also significantly reduced U.S. No. 1 yield. There is evidence that ethylene is inhibitory to potato tuberization (Mingo-Castel et al., 1974). The sensitivity to split applications may have been accentuated by the growing conditions in 1988. Extended periods of high temperature may have stressed plants, resulting in the production of ethylene and inhibition of tuber development (Table 2). The plants may have been more sensitive to ethephon and 2,4-D in the later stage of tuberization; however, this was not measured. Single applications of either ethephon or 2,4-D did not significantly affect tuber yield in 1988 (Table 1). Total yields were not affected in either year by split, double-rate applications of ethephon and double-rate applications of 2,4-D. However, these treatments were accompanied by extensive growth cracking and the production of many undesirably small tubers (data not shown). Objective color analysis of the periderm in 1988 suggested that intensity in storage was greatest in tubers treated with a double-rate application of 2,4-D (Table 3); however, these differences could not be detected visually.

Foliar applications of either ethephon or 2,4-D can result in significant yield reductions and do not affect periderm color intensity at harvest or throughout storage sufficiently to warrant their use. Improved periderm color in red-skinned potatoes should be achieved through breeding and cultivar selection for specific production regions.

\section{Literature Cited}

Armitage, A.M. 1989. Promotion of fruit ripening of ornamental peppers by ethephon. HortScience 24:962-964.

Burg, S. P. and E. A. Burg. 1965. Ethylene action and ripening of fruits. Science 148: 1190-1 196.

Cantliffe, D. J. and P. Goodwin. 1975. Red color enhancement of pepper fruits by multiple applications of ethephon. J. Amer. Soc. Hort. Sci. 100:157-161.

Edwards, J. I., W.R. Henderson, and M.E. Saltveit. 1984. Yield and quality of processing field grown tomatoes as influenced by inhibitors of ethylene biosynthesis. HortScience 19:579-580.

Francis, F.J. 1982. Analysis of anthocyanins, p. 181-207. In: P. Markakis (ed.). Anthocyanins as food colors. Academic, New York.

Grange, G.R. 1972. United States standards for grades of potatoes. U.S. Dept. Agr. Publ. F. R. Doc. 70-15938.

Knavel, D.E. and T.R. Kemp. 1973. Ethephon and CPTA on color development in bell pepper fruits. HortScience 8:403-404. 
Mingo-Castel, A. M., F.B. Negro, and O.E. Smith. 1974. Effect of carbon dioxide and ethylene on tuberization of isolated potato stolon cultured in vitro. Plant Physiol. 53:798-801.
Nelson, D.C. and D.W. Bristol. 1975. 2,4-D on potatoes. Agr. Ext. Serv. Univ. of Minnesota and North Dakota State Univ. Red River Valley Potato Facts no. 5
Worku, Z., R.C. Herner, and R.L. Carolus. 1975. Effect of stage of ripening and ethephon treatment on color content of paprika pepper. Scientia Hort. 3:239-245. 